\title{
EVALUATION OF DES-GAMMA CARBOXY PROTHROMBIN AS A BIOMARKER FOR EARLY DETECTION OF HEPATOCELLULAR CARCINOMA ON TOP OF CHRONIC ACTIVE HEPATITIS POST VIRUS C INFECTION
}

By

\section{Ahmed Al-Sayed Saied Attia, Magdy Zaki El-Ghannam, Maged Abd El- Fattah Shalaby, Khaled Ahmed Mohammed* and El-Sayed Mohamed Abd El-Hamid**}

Departments of Clinical Pathology, Hepatology, Gastroenterology \& Infectious diseases* and Radiology**, Faculty of Medicine, Al-Azhar University, (Cairo and Damietta)

Corresponding author: Ahmed Al-Sayed Saied Attia,

E-mail: elhanafya18@gmail.com

\begin{abstract}
Background: Experience with Des-gamma Carboxy Prothrombin (DCP) is limited. Most studies on HCC biomarkers have focused on the accuracy of markers for diagnosis.

Objective: To assess serum level of Des-gamma carboxy prothrombin as a biomarker for early detection of hepatocellular carcinoma post chronic active hepatitis on top of hepatitis $\mathrm{C}$ virus infection (HCV).

Patients and Methods: This study was conducted on 60 individuals diagnosed as chronic HCV patients, and 30 healthy individuals were selected as a control group. Fifteen patients were suffering from chronic active hepatitis without complications, Fifteen patients were suffering from chronic active hepatitis with complications, Fifteen patients were of early cases of $\mathrm{HCC}$ on top of $\mathrm{HCV}$, and Fifteen were patients of late cases of HCC on top of HCV. Des-gamma Carboxy Prothrombin were measured by ELISA.
\end{abstract}

Results: There was significant increase in Des-gamma Carboxy Prothrombin (DCP) in group (II) and group (III) when compared to control group (I). However, Patients in group (III) showed higher levels of DCP when compared to group (II).

Conclusion: DCP was promising in overcome AFP insufficiency in identity AFP negative HCC as DCP has a superior performance than AFP in identification of HCC from HCV-related in surveillance studies.

Keywords: Hepatitis C, Hepatocellular Carcinoma, Des-gama Carboxy Prothrombin, Early Detection.

\section{INTRODUCTION}

Hepatocellular carcinoma (HCC) is the sixth most common malignancy and the third most common cause of cancerrelated death worldwide (Kamangar et al., 2011). The incidence of HCC is increasing and is largely attributed to hepatitis C. While the survival of patients with most malignancies has improved over the last decade, 5-year survival of patients with HCC has remained less than 10\% (El-Serag, 2014).

The poor outcome of patients with $\mathrm{HCC}$ is related to the late detection with 
more than two-thirds of patients diagnosed at advanced stages of disease. Cirrhosis of any cause and chronic infection with hepatitis B virus (HBV) or hepatitis $\mathrm{C}$ virus (HCV) are the most common risk factors for HCC (Llovet et al., 2012). Thus, surveillance of populations at-risk may detect tumors at an early stage when curative interventions can be implemented. Several studies reported a benefit of HCC surveillance on survival and guidelines from professional organizations recommend HCC surveillance for at-risk populations (Bruix et al., 2011).

Des-gamma-carboxy prothrombin (DCP) is an abnormal prothrombin molecule that is generated as a result of an acquired defect in the post translational carboxylation of the prothrombin precursor in malignant cells, this prothrombin defect in malignant cells is similar to the deficit in vitamin $\mathrm{K}$ deficiency and has been called prothrombin induced by vitamin $\mathrm{K}$ absence (PIVKA) (Liebman et al., 2015). Experience with DCP in western countries, particularly the United States, is limited. Most studies on HCC biomarkers have focused on the accuracy of these markers at the time of HCC diagnosis. Few studies have included cohorts of atrisk persons followed prospectively to determine the utility of these markers in detecting early stage $\mathrm{HCC}$, before clinical manifestations (Marrero, 2011).

Some studies included patients with early stage liver disease, who are at low risk of $\mathrm{HCC}$, and in most studies, the performance of the biomarkers was assessed by focusing on baseline values rather than on serial determinations over time (Ikoma et al., 2012).

This study aimed to assess serum level of Des-gamma carboxy prothrombin as a biomarker for early detection of hepatocellular carcinoma post liver cirrhosis on top of hepatitis $\mathrm{C}$ virus infection.

\section{PATIENTS AND METHODS}

The present study was conducted on 60 individuals diagnosed as chronic $\mathrm{HCV}$ patients. They were selected from outpatient clinic and inpatient of Hepatology, Gastroenterology and Infectious Diseases Department of New Damietta Hospital of Al-Azhar University. Thirty healthy individuals matched for age and sex were selected as a control group. They were classified into three groups as follow: Group (I): Control Group included 30 individuals apparent healthy. Group (II): Patients with chronic active hepatitis post virus $\mathrm{C}$ included 30 patients and divided into two sub-groups: 15 patients suffering from compensated cirrhosis and 15 patients suffering from decompensated cirrhosis hepatitis with complications (advanced stage with liver cirrhosis). Group (III): Patients with HCC on top of chronic active hepatitis post virus $\mathrm{C}$ infection included 30 patients and divided into two sub-groups: 15 patients of early cases of HCC and 15 patients of late cases of HCC.

All included subjects were submitted to full history taking, clinical examinations, radiological investigations and laboratory investigations including complete blood count (CBC), liver function tests, renal function tests, prothrombin time (PT) and 
INR, erythrocyte sedimentation rate (ESR), viral markers (HBsAg \& HCVAb), alfa feto protein and des-gamma Carboxy Prothrombin by ELISA Kit (Glori Science), Germany done by (Tecan Sun Rise, Germany).

\section{Statistical analysis:}

All data were collected, tabulated and statistically analyzed using SPSS 22.0 for windows (SPSS Inc., Chicago, IL, USA). One-way ANOVA with Post-hos test were used to calculate difference between quantitative variables in three groups for parametric and non-parametric variables respectively. Receiver operating characteristic (ROC) curve was constructed to permit selection of threshold values for test results and comparison of different testing strategies. All statistical comparisons with significance level of $\mathrm{P}$-value $\leq 0.05$ indicates significant.

\section{RESULTS}

There were significant decreases in TLC, $\mathrm{Hb}$ and Platelets in group II and group III when compared to control group I. However, patients in group III showed lower levels of TLC, $\mathrm{Hb}$ and platelets when compared to group II. There were significant increases in ALT, AST, total bilirubin and INR and significant decrease in albumin in group II and group III when compared to control group I. However, patients in group III showed higher levels of ALT, AST, total bilirubin, INR and lower levels in albumin when compared to group II. There was significant increase in Alfa Feto protein (AFP) in group II and group III when compared to control group I. However, Patients in group (III) showed higher levels of AFP when compared to group II. There was significant increase in Des-gamma Carboxy Prothrombin (DCP) in group II and group III when compared to control group I. However, patients in group (III) showed higher levels of DCP when compared to group II (Table 1).

Table (1): Comparison between laboratory parameters between studied groups $($ Mean \pm SD)

\begin{tabular}{|c|c|c|c|c|c|c|}
\hline Groups & $\begin{array}{c}\text { Control } \\
\text { group } \\
(\mathbf{n}=\mathbf{3 0})\end{array}$ & $\begin{array}{c}\text { Early } \\
\text { cirrhosis } \\
\text { group } \\
(\mathbf{n}=\mathbf{1 5}) \\
\end{array}$ & $\begin{array}{c}\text { Late } \\
\text { cirrhosis } \\
\text { group } \\
(\mathbf{n}=\mathbf{1 5})\end{array}$ & $\begin{array}{c}\text { Early HCC } \\
\text { group } \\
(\mathbf{n}=\mathbf{1 5})\end{array}$ & $\begin{array}{c}\text { Late } \mathrm{HCC} \\
\text { group } \\
(\mathbf{n}=\mathbf{1 5})\end{array}$ & $\begin{array}{c}\mathbf{P} \\
\text { value }\end{array}$ \\
\hline TLC $\left(10^{3} / \mathrm{ul}\right)$ & & $6.6 \pm 3.4$ & $3.9 \pm 0.9$ & & & 0.001 \\
\hline RBC $\left(10^{3} / \mathrm{ul}\right)$ & & 3. & 3.5 & & & 0.001 \\
\hline $\mathrm{Hb}(\mathrm{g} / \mathrm{dl})$ & & & 9.7 & & 1.6 & 0.001 \\
\hline Plat (10'3/ul) & & 137 & 73 & & & 0.01 \\
\hline ALT (U/L) & & $66 \pm 2$ & $79 \pm 2$ & & & 0.001 \\
\hline AST (U/L) & & & $95 \pm$ & & & 0.001 \\
\hline TB (mg/dl) & $0.6 \pm 0.2$ & $2.15 \pm 0.8$ & $3.56 \pm 1.2$ & $2.99 \pm 0.7$ & $9 \pm 0.5$ & 0.001 \\
\hline Albumin (g/dl) & & $3.38 \pm 0.3$ & $2.46 \pm 0.3$ & & $3 \pm 0.2$ & 0.01 \\
\hline INR & & & $1.6 \pm 0$ & & & 0.01 \\
\hline $\operatorname{AFP}(\mathbf{n g} / \mathrm{ml})$ & & $7.5 \pm 2.1$ & $16.3 \pm 3.1$ & $68.4 \pm 13.1$ & $153 \pm 42$ & 0.01 \\
\hline DCP (mAU/ml) & $28.4 \pm 6.8$ & $68.6 \pm 20.1$ & $85.3 \pm 27.2$ & $100.7 \pm 16.7$ & $125 \pm 28.2$ & 0.001 \\
\hline
\end{tabular}


Accuracy of DCP for differentiate HCC from controlled was $85.07 \%$, sensitivity $83.77 \%$, specificity $90.32 \%$ at a cutoff value of $40 \mathrm{mAU} / \mathrm{ml}$, and the
Accuracy of AFP was $79.82 \%$, sensitivity $66.08 \%$ and specificity of $82.49 \%$ at a cutoff value of $20 \mathrm{ng} / \mathrm{ml}$ (Table 2 and Figure 1).

Table (2): Measurement of DCP and AFP in diagnosis of HCC in Cirrhosis and HCC groups

\begin{tabular}{|c|c|c|c|c|c|c|}
\hline & Sensitivity & Specificity & Accuracy & PPV \% & NPV \% & CI 95\% \\
\hline DCP & $83.61 \%$ & $85.01 \%$ & $80.41 \%$ & 88.96 & 70.33 & 0.841 \\
\hline AFP & $65.01 \%$ & $79.55 \%$ & $70.82 \%$ & 85.61 & 58.22 & 0.799 \\
\hline
\end{tabular}

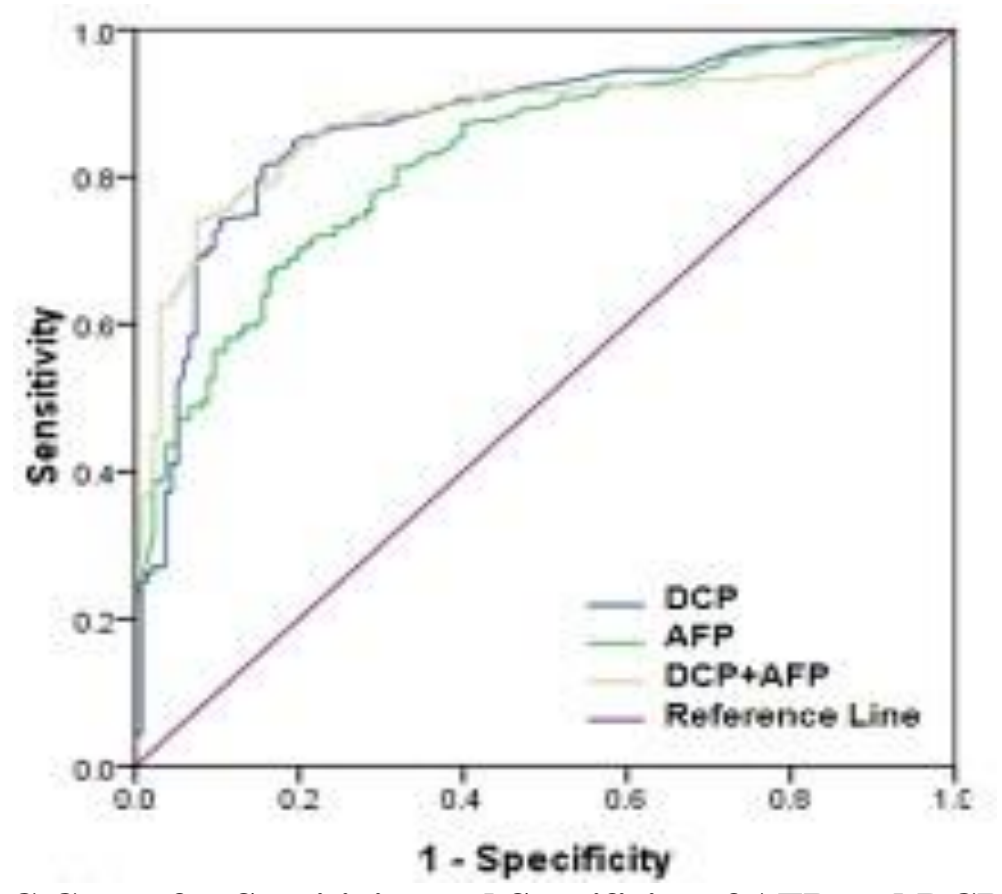

Figure (1): ROC Curve for Sensitivity and Specificity of AFP and DCP

\section{DISCUSSION}

The present study was conducted on 60 individuals diagnosed as chronic $\mathrm{HCV}$ patients and 30 healthy individuals were selected as a control group. They were classified into three groups as follow: Group (I): "Control Group": included 30 individuals apparent healthy. Group (II): "patients with chronic active hepatitis post virus C": included 30 patients and divided into two sub-groups: 15 patients suffering from compensated cirrhosis and 15
Patients suffering from chronic active hepatitis with complications (decompensated cirrhosis). Group (III): "Patients with HCC on top of chronic active hepatitis post virus $\mathrm{C}$ infection": included 30 patients and divided into two sub-groups: 15 patients of early cases of HCC and 15 Patients of late cases of HCC.

There was significant difference between the three studied groups regarding to Hematological findings, there was significant decrease in TLC, $\mathrm{Hb}$ and 
Platelets in group (II) and group (III) when compared to control group (I). However, Patients in group (III) showed lower levels of TLC, $\mathrm{Hb}$ and Platelets when compared to group (II).

This was in agreement with what reported by Gad et al. (2011) that significantly lower levels of platelet count were seen in cirrhosis and HCC patients. There were statistically insignificant differences between cirrhosis, HCC and control groups as regard to WBCs.

Regarding to liver function tests, there were significant increases in ALT, AST, total bilirubin and INR and significant decrease in albumin in group (II) and group (III) when compared to control group (I). However, patients in group (III) showed higher levels of ALT, AST, Total bilirubin, INR and lower levels in albumin when compared to group (II).

This finding was close to study of Anber et al. (2016) who reported that the serum level of AST and ALT were elevated in their studied HCC patients. Serum AST was higher than ALT and the difference becomes greater as the disease progresses. Also, low serum albumin concentration and prolongation of prothrombin time in HCC. His explanations that the onset of rapid deterioration in cirrhotic patients with decrease synthetic functions of liver may signal the development of HCC with low serum albumin concentration and prolongation of prothrombin time.

There were significant increases in Alfa feto protein (AFP) and Des-gamma Carboxy Prothrombin (DCP) in group (II) and group (III) when compared to control group (I). However, patients in group (III) showed higher levels of AFP when compared to group (II). The results demonstrated that the accuracy and sensitivity of DCP were higher than that of AFP at the cutoff levels of $40 \mathrm{mAU} / \mathrm{ml}$ (DCP) and $20 \mathrm{ng} / \mathrm{ml}$ (AFP).

Beside of high diagnostic performance of DCP, we found that DCP had a superior performance than AFP in identification of HCC from HCV-related non-HCC, differentiate between HCC and liver cirrhosis, and high capacity for identifying $\mathrm{HCC}$ with negative AFP.

AFP elevation could occur in approximately $11-47 \%$ of subjects with liver cirrhosis, and a false-negative AFP appeared in $30-40 \%$ of subjects with hepatocellular carcinoma (HCC) (Farinati et al., 2010). The elevated positive proportions of DCP are similar and even better than most findings in HCV-related $\mathrm{HCC}$, indicating that DCP is suitable and superior to AFP for $\mathrm{HBV}$-related $\mathrm{HCC}$ surveillance ( $\mathrm{Li}$ et al., 2014). DCP is produced by $\mathrm{HCC}$ and can conversely stimulate the growth and invasion of HCC through different signal pathways (Cui et al., 2016).

The cutoff point of DCP differed from study to another, ranged from 32.09 to $49.05 \mathrm{mAU} / \mathrm{ml}$ (Chen et al., 2018). In our study, the cutoff point was $40 \mathrm{mAU} / \mathrm{ml}$, and diagnosis of HCC was made upon radiological examination. And cutoff point on AFP was $20 \mathrm{ng} / \mathrm{ml}$.

We find that higher DCP levels were significantly associated with aggressive tumor behavior and poor liver function. Our results revealed high sensitivity and specificity of DCP over AFP to distinguish between controlled group and HCC group (83.7, 90.33\% - 66, 89.49\%) respectively, and $(83.6,85 \%-65.79 .5 \%)$ 
sensitivity and specificity of DCP and AFP in differentiation between cirrhotic and $\mathrm{HCC}$ groups.

In a single study made in china between liver diseased group and HCC group the sensitivity of DCP was 74 and 62\% respectively (Song et al., 2013). Another multicentric study from china the sensitivity and specificity were (82.6, 78.5\%-90.7, 69\%) for DCP and AFP which similar to our study ( $\mathrm{Ji}$ et al., 2016). In large meta-analysis three studies with $\mathrm{HCV}$ infected population the sensitivity and specificity of DCP ranged from $52-85 \%$ and $81-97 \%$ respectively (Cui et al., 2016).

Our study showed the superiority of DCP over AFP in diagnosis of HCC and diagnose if HCC negative AFP patients which supported by study of $J i$ et al. (2016).

\section{CONCLUSION}

DCP was promising in overcome AFP insufficiency in identity AFP negative HCC as DCP had a superior performance than AFP in identification of HCC from HCV-related in surveillance studies.

\section{Financial and Non-Financial Relationship and Activities of Interest: None declared by the authors.}

\section{REFERENCES}

1. Anber NH, El-Ghannam MZ, El-Kheshen GA and Bialy MI. (2016): Evaluation of serum zinc level in Egyptian patients with hepatitis C-associated cirrhosis. Journal of Pharmaceutical and Biomedical Sciences, 6(2): 81-85.

2. Bruix J, Sherman M, Llovet JM, Beaugrand $\mathrm{M}$, Lencioni R, Burroughs AK and Rodés J. (2011): Clinical management of hepatocellular carcinoma. Conclusions of the Barcelona-2000
EASL conference. Journal of Hepatology, 35(3): 421-430.

3. Chen J, Wu G and Li Y. (2018): Evaluation of serum des-gamma-carboxy prothrombin for the diagnosis of hepatitis $\mathrm{B}$ virus-related hepatocellular carcinoma: a meta-analysis. Disease Markers, 3: 10-15.

4. Cui SX, Yu XF and Qu XJ. (2016): Roles and signaling pathways of des- $\gamma$ carboxyprothrombin in the progression of hepatocellular carcinoma. Cancer Investigation, 34(9): 459-464.

5. El-Serag HB. (2014): Hepatocellular carcinoma recent trends in the United States. Gastroenterology, 127: 27-34.

6. Farinati F, Marino D, De Giorgio M, Baldan A, Cantarini M, Cursaro $C$ and Zoli $M$. (2010): Diagnostic and prognostic role of $\alpha$ fetoprotein in hepatocellular carcinoma: both or neither? American Journal of Gastroenterology, 101(3): 524-532.

7. Gad A, Tanaka E, Matsumoto A, Abd-el Wahab M, Serwah AEH, Attia F, and Umemura, T. (2011): Assessment of KL-6 as a tumor marker in patients with hepatocellular carcinoma. World Journal of Gastroenterology, 11(42): 6607.

8. Ikoma J, Kaito M, Ishihara T, Nakagawa N, Kamei A, Fujita N, Iwasa M, Tamaki S, Watanabe S and Adachi Y. (2012): Early diagnosis of hepatocellular carcinoma using a sensitive assay for serum des-gamma carboxy prothrombin: a prospective study. Hepatogastroenterology, 49:235-38.

9. Ji J, Wang H, Li Y, Zheng L, Yin Y, Zou Z and Gao C. (2016): Diagnostic evaluation of des-gamma-carboxy prothrombin versus $\alpha$ fetoprotein for hepatitis B virus-related hepatocellular carcinoma in China: a largescale, multicentre study. PloS one, 11(4): 153227-32.

10. Kamangar F, Dores GM and Anderson WF. (2011): Patterns of cancer incidence, mortality, and prevalence across five continents: defining priorities to reduce cancer disparities in different geographic regions of the world. Journal of Clinical Oncology, 24(14): 21372150. 
11. Li C, Zhang Z, Zhang $P$ and Liu J. (2014): Diagnostic accuracy of des-gamma-carboxy prothrombin versus $\alpha$-fetoprotein for hepatocellular carcinoma: A systematic review. Hepatology Research, 44(10): 11-25.

12. Liebman HA, Furie BC, Tong MJ, Blanchard RA, Lo KJ, Lee SD, Coleman MS and Furie B. (2015): Des-gamma carboxy (abnormal) prothrombin as a serum marker of primary hepatocellular carcinoma. N Engl J Med., 310:1427-1431.

13. Llovet JM, Di Bisceglie AM, Bruix J, Kramer BS, Lencioni R, Zhu AX, and Gores GJ. (2012): Design and endpoints of clinical trials in hepatocellular carcinoma. Journal of the National Cancer Institute, 100(10): 698711 .
14. Marrero JA. (2011): Screening tests for hepatocellular carcinoma. Clin Liver Dis., 9:235-251.

15. Shi SY, Luk CT, Schroer SA, Kim MJ, Dodington DW, Sivasubramaniyam $T$ and Bazinet RP. (2017): Janus Kinase 2 (JAK2) dissociates hepatosteatosis from hepatocellular carcinoma in mice. Journal of Biological Chemistry, 292(9): 3789-3799.

16. Song $P$, Feng $X$, Zhang $K$, Song $T$, Ma $K$, Kokudo N and Tang W. (2013): Screening for and surveillance of high-risk patients with HBV-related chronic liver disease: promoting the early detection of hepatocellular carcinoma in China. Bioscience Trends, 7(1): 1-6. 
تقيبه مستوي دس جاما كاربوكسي بروثرومبينز كلالالة مبكرة لتشثخيص

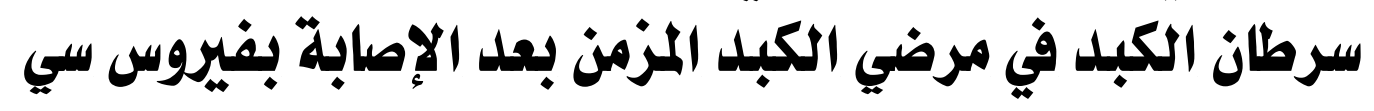
أحمد السيد سعيد عطيه, مجدي ذكي الغنام, ماجد عبد الفتاح شلبي, خالد الملاث, السيد ***ممد عبد الحميل

أقسام الباثولوجيا الإكلينيكية, وقسم الكبد والجهاز الهضمي والأمراض المعدية*, وقسم الأثعةث**,

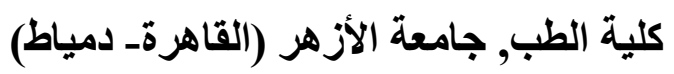

E-mail: elhanafya18@gmail.com

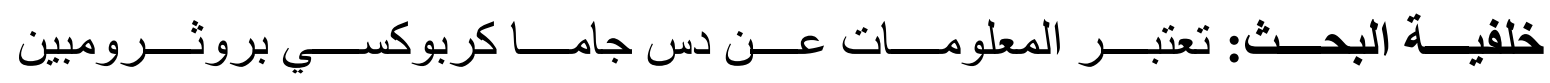

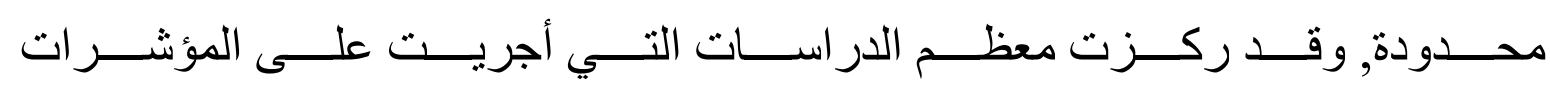

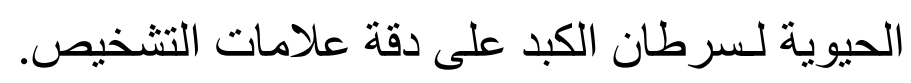

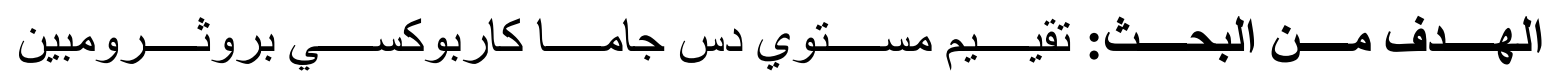

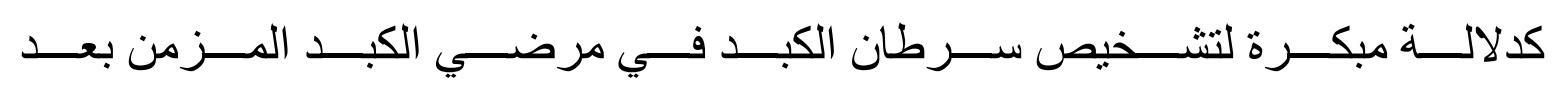
الإصابة بفيروس سي.

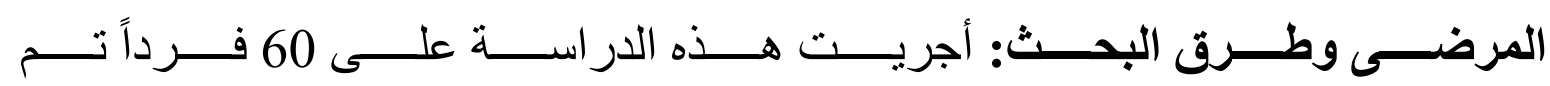

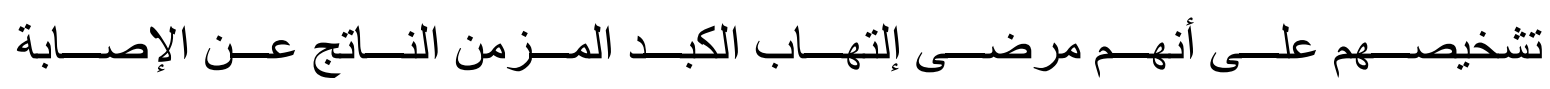

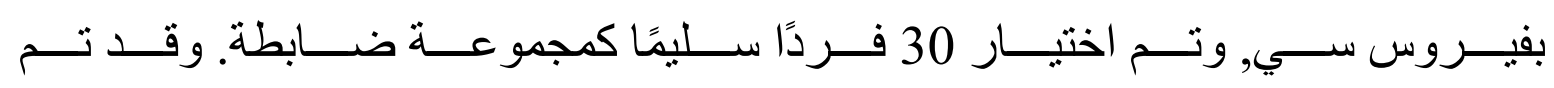

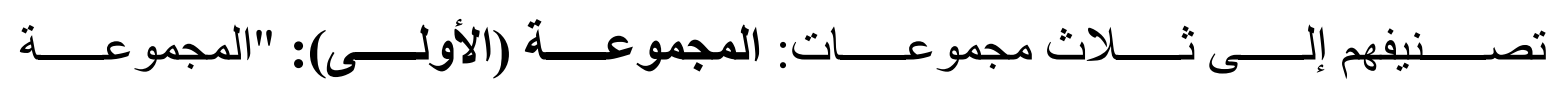

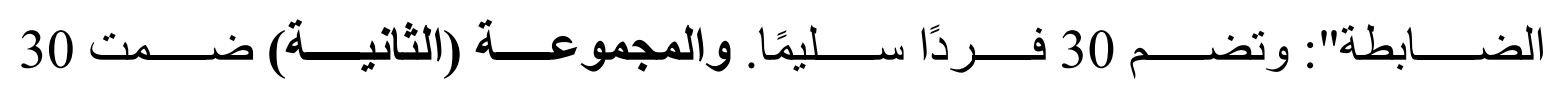

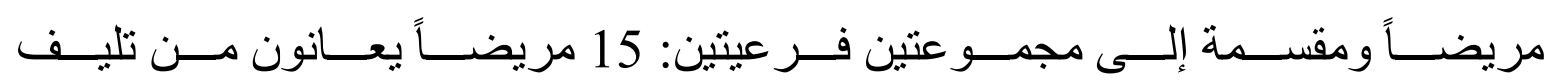

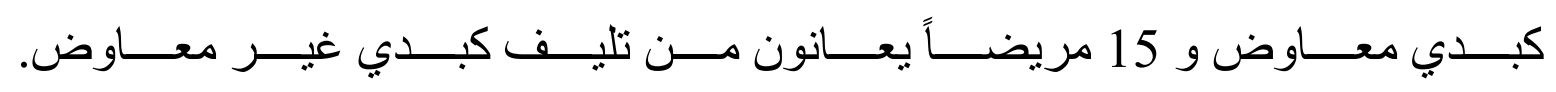

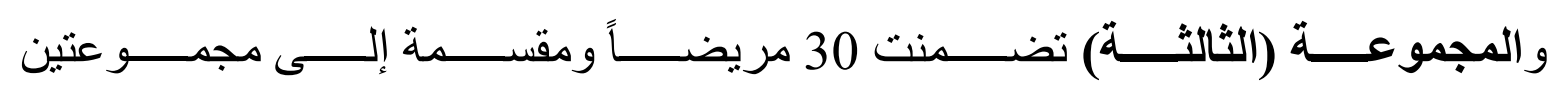

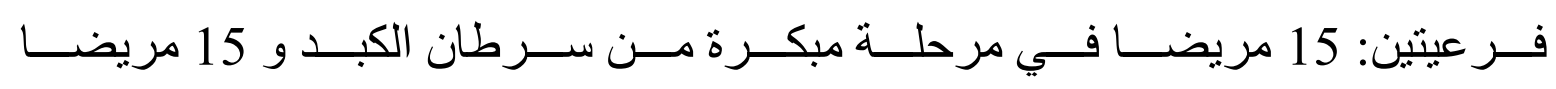
في مرحلة متأخرة بعد الإصـابة بفيروس سي. مربئ مرحس 


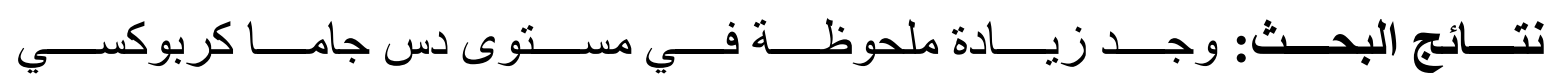

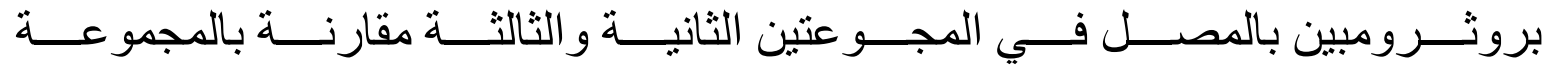

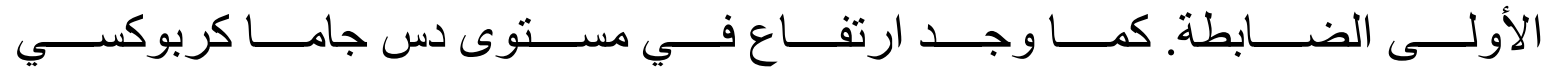
بروثرومبين بالمصل في المجمو عة الثالثة مقارنة بالمجمو عة الثانية.

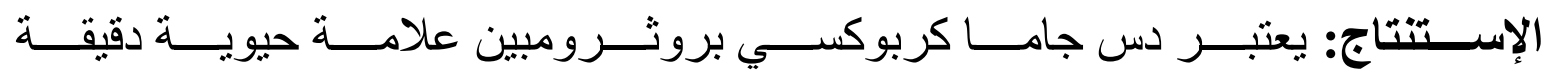

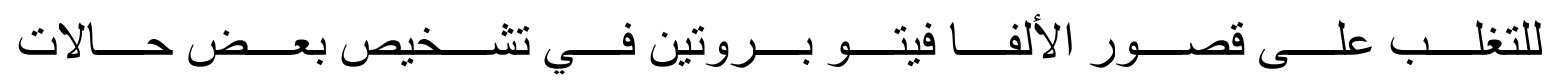

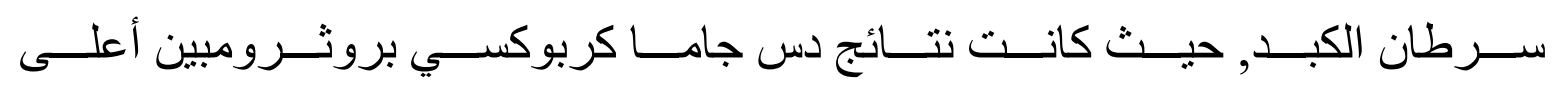
في تحديد سرطان الكبد بعد الإصسابة بفيروس سي.

الكلمـــات الدالــة: الإلتهــاب الكبــدي ســـي، ســرطان الخلايـــا الكبديـــة، دس جامــــا كربو كسي بروثزو مبين، الاكثشاف المبكر. 